\title{
Factors Influencing the Employee Job Satisfaction and Organizational Commitment: A Study of Selected Commercial Banks in Bangladesh
}

\author{
ANM Jahangir Kabir \\ Professor, Department of Management Studies, University of Rajshahi, Rajshahi-6205, BANGLADESH \\ E-mail for correspondence: anmjk@ru.ac.bd
}

https://doi.org/10.18034/abr.v8i3.160

\begin{abstract}
This article strives to determine the most influential factors giving rise to employee job satisfaction and organizational commitment in the commercial banks of Bangladesh. Accordingly, the study aims at exploring the extent to which these employees are committed to their organizations and satisfied with different dimensions of their jobs. This study was conducted on the employees of commercial banks of Bangladesh. Out of the 300 survey questionnaires distributed among the respondents, 285 statistically usable questionnaires were received. A stepwise descriptive statistic, multiple regression analysis and one-way-ANOVA were used to confirm the research hypotheses. The findings of the study indicated that reward and recognition, authority and feedback are highly influential factors influencing job satisfaction. Authority and feedback for affective commitment, work and working environment for continuance commitment and supervisor, and supervision for normative commitment have been found to be the most influential factors.
\end{abstract}

Key words: Job satisfaction, Organizational commitment, Affective commitment, Continuance Commitment, Normative Commitment

\section{INTRODUCTION}

Job satisfaction refers to the affective orientations the individuals have toward work roles which they play while performing the jobs. In other words, job satisfaction can be understood as the way employees feel about their jobs and different aspects thereof (Kreitner \& Kinicki, 2006). Job satisfaction is an attitudinal product of an employee's perception as to how well his or her job provides him or her with the things that are deemed to be important (Luthans, 2011). There are three dimensions to job satisfaction. First, job satisfaction is an emotional response to a job situation- as it cannot be seen, but it can only be inferred. Second, job satisfaction is often determined by the extent to which an employee's expectations are met. Third, job satisfaction represents several attitudes relating to the work itself (The extent to which the job provides the employee with interesting tasks, opportunities for learning, and the chance to accept responsibility), pay (the degree to which the pay is viewed as equitable), Promotion opportunities (The chances for advancement), Supervision (The abilities of the supervisor to provide support), and Coworkers (The degree to which fellow workers are supportive) (Luthans, 2011, 141).

Job satisfaction is subjected to the influence of a myriad of factors, among which the kind of work, salary, advancement opportunities, management style, nature of work groups and work conditions are found to be most important.

Job satisfaction is the resultant product of many external factors as well as something internal that are associated with the way the employees feel. That is, job satisfaction is the outcome of the interplay of a set of factors that cause a feeling of satisfaction.

Organizational commitment is an individual's psychological attachment to the organization. The more an employee has the psychological attachment to his or her organization the more he or she will incline to be identified with the organization. Organization commitment can be defined as the affiliation of employees to the organization and involvement in it (Nawab and Bhatti, 2011). 
There are three components of organizational commitment, namely, Affective Commitment, which is concerned with psychological attachment to organization; Continuance Commitment, which is associated with costs of leaving the organization; and Normative Commitment, which refers to employees' sense of obligation to remain with the organization and continuing participation of the individual in the organization (Tella et al., 2007). Employees having stable work experiences and fulfilled their fundamental needs with substantial progress within the organization tend to develop affective commitment (Meyer et al., 1993). Mowday et al. (1982) maintained that affective organizational commitment is "a strong belief in and acceptance of the organization's goals and values; a willingness to employ considerable effort on behalf of the organization; and a strong wish to maintain membership in the organization." Meyer et al. (2002) indicated that skills and education are not easily transferred to other organization which tends to increase workers' continuance commitment to their current organizations. Continuance organizational commitment, which considers the idea that individuals do not leave a company for fear of losing their benefits, suffering a pay cut, and not being able to find another job (Murray et al., 1991).

It can be said that normative commitment to the organization develops based on a collection of pressures that individuals feel during their early socialization from family and culture, and during their early socialization as newcomers to the organization. Normative commitment is said to have increased when an individual feels allegiant to his employer or develop a sense of responsibility for getting the work done for the benefits that he gets from the organization because of desire for offsetting the favors he or she receives from the institution (Meyer et al., 2002).

\section{LITERATURE REVIEW}

Busch et al., (1998); Chiu-Yueh (2000); Freund (2005); Mannheim et al., (1997) found that job satisfaction was a significant predictor of organizational commitment. Some researchers argued that job satisfaction reflects immediate affective reactions to the job while commitment to the organization develops more slowly after the individuals have formed more comprehensive valuations of the employing organization, its values and expectations and one's own future in it. Curry et al. (1986) found no significant relationship between job satisfaction and organizational commitment.

Porter et al. (1974) pointed out organizational commitment as the "relative strength of an individual's identification with and involvement in a particular organization." According to Meyer and Allen (1997), "Individuals who have strong affective commitment remain in the organization because they feel they want to, some with a stronger normative commitment remain because they ought to and those with strong continuance commitment remain because they need to." According to Meyer et al. (2002), job satisfaction is a determinant of organizational commitment. The main difference between organizational commitment and job satisfaction is that while organizational commitment can be defined as the emotional responses which an employee has towards his organization; job satisfaction is the responses that an employee has towards any job. It is considered that these two variables are highly interrelated. When an employee has positive feelings towards the organization, its values, and objectives, it is impossible for him to be unsatisfied with the job he is doing in the organization (Çelik, 2008). Many researches empirical in nature have indicated that there is a low correlation between job satisfaction, commitment, and the intention to leave an organization, which also suggests that no direct relationship exists among them. There are satisfied, committed employees who decide to leave, and dissatisfied, ambivalent employees who steadfastly remain at their jobs (Nunn, 2000; Norizan, 2012).

Daneshfard and Ekvaniyan (2012) found that when organizational commitments such as affective and normative commitments increase job satisfaction increases too. Again, when organizational commitment (affective and normative commitment) decrease employees and mangers' job satisfaction decrease too. Eslami and Gharakhani (2012) found that job satisfaction has positive and significant effects on organizational commitments.

\section{RATIONALE OF STUDY}

An employee who is satisfied with his job is likely to perform his duties well and be more committed to his job, and in turn to the organization. The employers need to know the factors that can affect their employees' job satisfaction level since it is in turn responsible for positively affecting the performance of the organization (Awang et al., 2010). Satisfaction is mainly concerned with the employee's attitude toward the job and commitment is concerned with an employee having (1) a strong desire to remain a member of a particular organization; (2) a willingness to exert high levels of effort on behalf of the organization; and (3) a definite belief in, and acceptance of, the values and goals of the organization. (Mowday et al., 1982).

The organizational commitment is a kind of attitude influenced by some personal and organizational variables. Personal variables include age, service length, adaptability to the job, and employee dispositions (positive or negative). On the other hand, organizational variables include the job design, values, support, procedural fairness, and the leadership style of one's supervisor.

There is a strong relationship between job satisfaction and organizational commitment that has been observed to prevail over the years (Luthans et al., 1987, 219-236).

Research reports that public sector managers have a lower level of job satisfaction than those of the private sector 
employees (Sokoya, 2000). Another finding of a study shows that employees in the private sector are having higher mean job satisfaction, organizational commitment, and intention to stay than those in the public sector. This finding supports the first hypothesis used in another study that agricultural technicians working in the public and semi-public sectors are having lower job satisfaction and organizational attachment than those working in the private sector (Mulinge, 2000).

Steers' model (1977) subsumes the antecedents of commitment into three major categories: personal categories, job characteristics and work experiences, Morris and Steer (1980) led to the addition of a fourth category, structural characteristics. Personal Category includes: age tenure, education, gender. Non-demographic individual difference variables include the need for achievement, sense of competence, higher order needs, strong personal work ethic, professionalism (O'Leary-Kelly and Griffin, 1995). The human resources are the core resources among other resources that give rise to a sustainable competitive advantage and the same holds for banking industry in Bangladesh like other organizations. For a service industry like banking, a desired level of employee job satisfaction and organizational commitment is of utmost importance. The job satisfaction of employees in a developing country like Bangladesh is also affected by shortages of economic resources, corruptions, political interference and instability, dysfunctions of bureaucracy (Khan and Jan 2014).

A good number of research works were conducted on job satisfaction and organizational commitment, but a few works were emphasizing on the job satisfaction together with the organizational commitment. The banking sector in any economy plays an essential role in the capital formation and thereby triggering the industrialization process, and through this propelling the economic pace of a country. Healthy banks and healthy economies seem to go side by side, where a healthy banking system depends on the efforts of the employees working therein, and how much effort the employees will exert depends on how satisfied they are with their jobs and how committed they are to the organization.

This study is an attempt to make the management people involved alive to the perceptions of employees under study with regard to their own job satisfaction and organizational commitment. The results of the work will help weave a blueprint considering the outcomes of this study to address judiciously the factors affecting the job satisfaction and organizational commitment.

\section{A Hypothetical Model Based on Literature REVIEW}

Based upon the literature review, following model is developed to show the relationship between job satisfaction and work-related factors; organizational commitment and work-related factors under study to examine and explore the relationships to the hypothetical dependent and independent variables.

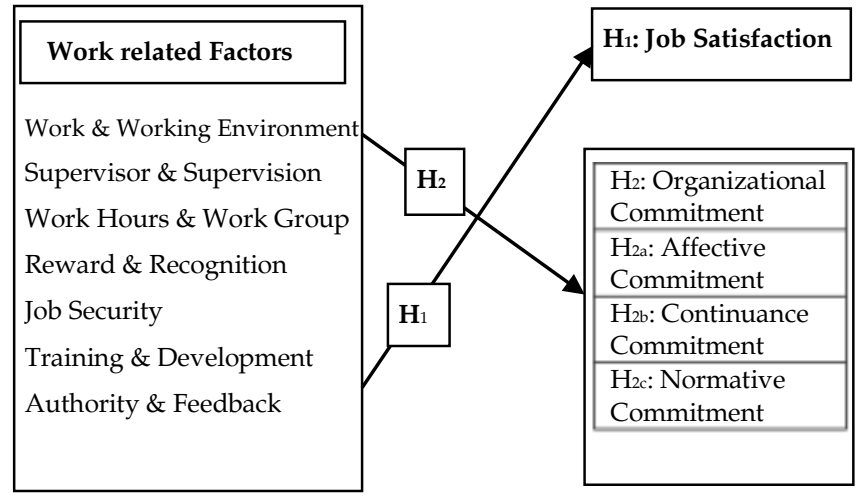

Source: Compiled by Authors

\section{Objectives of the Study}

The study has focused on the attributes giving rise to job satisfaction and organizational commitment among employees in the commercial banks of Bangladesh. This study has been conducted in line with the following objectives:

- To examine the various factors influencing the employee job satisfaction and organizational commitment.

- To explore the relationships between the various types of commitment and factors affecting the employee commitment in the commercial banks under the study.

- To explore the relationships between the job satisfaction and factors affecting the employee job satisfaction in the commercial banks under the study.

- To explore the association between job satisfaction and components of organizational commitment.

\section{HYPOTHESES}

$\mathbf{H}_{1}$ : There exists a positive and significant association between job satisfaction and work-related factors in the commercial banks of Bangladesh under study.

$\mathbf{H}_{2}$ : There is an association between affective commitment and work-related factors in the commercial banks of Bangladesh under study.

$\mathbf{H}_{3:} \quad$ There is a positive and significant association between continuance commitment and workrelated factors in the commercial banks of Bangladesh under study.

$\mathbf{H}_{4} \quad$ There is a positive and significant association between normative commitment and work-related factors in the commercial banks of Bangladesh under study.

\section{Methodology OF THE STUdy}

This study is an exploratory one developed by previous literature with a desire for coming up with factors influencing job satisfaction and organizational commitment in the financial institutions of Bangladesh. Both primary and secondary data have been used to collect the relevant 
data. An extensive survey has been made to collect the primary data from the employees mainly using a questionnaire. There are 56 (approximately) banks operating in Bangladesh. A total number of 15 banks have been selected using cluster sampling method following the Tippett's random number table. A total number of 300 questionnaires were distributed among the employees working in the so selected 15 banks. The questionnaire was designed keeping in mind the research objectives comprising three parts such as part I containing questions relating to the demographic information of the respondent, Part II containing the questions relating to job satisfaction, and part III covering the questions relating to Organizational Commitment. Part II and part III have been designed to have the reactions of the respondents on a fivepoint Likert scale. The statistical computer package SPSS version IBM 20.0 is the most common research software, which has been used to analyze the data collected.

\section{Data Analysis}

To fulfill the objectives of this study, the data have been analyzed resorting to statistical tools of the statistical package - SPSS version -20(IBM), which included 1. Reliability analysis; 2. Descriptive statistics (Frequency Distribution); 3. Correlation analysis; 4. Regression analysis; 5. Hypothesis Testing.

\section{RESULTS AND Discussions}

An analysis of the data has been made to satisfy the objectives of the study. At the very outset, Cronbach's (alpha) has been used as an estimate of the reliability. Alpha coefficient ranges in value from 0 to 1 and may be used to describe the reliability of factors extracted from dichotomous (that is, questions with two possible answers) and multi-point formatted questionnaires or scales (i.e., rating scale: 1 = poor, $5=$ excellent). The reliability is proportionate to the value of Cronbach's alpha. Nunnaly (1978) indicated 0.70 to be an acceptable reliability coefficient but lower thresholds are sometimes used in the literature.

Table 1: Reliability Statistics

\begin{tabular}{|c|c|c|}
\hline $\begin{array}{c}\text { Cronbach's } \\
\text { Alpha }\end{array}$ & $\begin{array}{c}\text { Cronbach's Alpha Based on } \\
\text { Standardized Items }\end{array}$ & $\begin{array}{c}\mathrm{N} \text { of } \\
\text { Items }\end{array}$ \\
\hline .706 & .769 & 17 \\
\hline
\end{tabular}

Source: Field survey November-2016 to February-2017

Table 1 shows the internal reliability, internal reliability of the instrument was checked up on using Cronbach's alpha. The result of Cronbach alpha is 0.706 which is above the standard value of 0.70 (Nunnally, 1978). Therefore, this is clear from the table that the instrument used in this study has strong internal reliability and it could be used with confidence for the application of further statistical analysis and interpretation.

The most recognized types of descriptive statistics such as mean, Standard Errors of Mean and Standard Deviations have been used, which are exhibited in the table 2:
Table 2: Demographic Statistics of the respondents working in Commercial Banks under study

\begin{tabular}{|c|c|c|c|c|c|}
\hline Variables & $\begin{array}{l}\text { Frequ } \\
\text { ency }\end{array}$ & $\begin{array}{c}\text { Percen } \\
\text { Tage }\end{array}$ & Mean & \begin{tabular}{c|} 
Standard \\
Errors of Mean
\end{tabular} & $\begin{array}{l}\text { Standard } \\
\text { Deviation }\end{array}$ \\
\hline \multicolumn{3}{|c|}{ Gender } & \multirow[t]{4}{*}{1.13} & \multirow[t]{4}{*}{.020} & \multirow[t]{4}{*}{.333} \\
\hline Male & 249 & 87.4 & & & \\
\hline Female & 36 & 12.6 & & & \\
\hline Total & 285 & 100.0 & & & \\
\hline \multicolumn{3}{|c|}{ Age } & \multirow[t]{6}{*}{2.08} & \multirow[t]{6}{*}{.060} & \multirow[t]{6}{*}{1.006} \\
\hline $18-25$ & 97 & 34.0 & & & \\
\hline $26-35$ & 104 & 36.5 & & & \\
\hline $36-45$ & 48 & 16.8 & & & \\
\hline 46-above & 36 & 12.6 & & & \\
\hline Total & 285 & 100.0 & & & \\
\hline \multicolumn{3}{|c|}{ Education Ability } & \multirow[t]{5}{*}{3.22} & \multirow[t]{5}{*}{.026} & \multirow[t]{5}{*}{.438} \\
\hline SSC & 1 & .4 & & & \\
\hline Graduation & 220 & 77.2 & & & \\
\hline Post-Graduation & 64 & 22.5 & & & \\
\hline Total & 285 & 100.0 & & & \\
\hline \multicolumn{3}{|c|}{ Marital Status } & \multirow[t]{4}{*}{1.49} & \multirow[t]{4}{*}{.030} & \multirow[t]{4}{*}{.508} \\
\hline Married & 147 & 51.6 & & & \\
\hline Unmarried & 138 & 48.4 & & & \\
\hline Total & 285 & 100.0 & & & \\
\hline \multicolumn{3}{|c|}{ Experience } & \multirow[t]{7}{*}{2.15} & \multirow[t]{7}{*}{.072} & \multirow[t]{7}{*}{1.207} \\
\hline $1-5$ & 124 & 43.5 & & & \\
\hline $6-10$ & 50 & $\mathbf{1 7 . 5}$ & & & \\
\hline $11-15$ & 66 & 23.2 & & & \\
\hline $16-20$ & 35 & 12.3 & & & \\
\hline 20 and above & 10 & 3.5 & & & \\
\hline Total & 285 & 100.0 & & & \\
\hline
\end{tabular}

Source: Field survey November-2016 to February-2017

The table 2 shows that $87.4 \%$ of the respondents of commercial banks are male, and $12.6 \%$ of the respondents are female among 285 respondents. The mean score for respondents' gender is 1.13, and the standard deviation is 0.333 (Standard Error of Mean is 0.020). Table presents the age distribution of the respondents. $34 \%$ of the respondents are between $18-25$ years of age, $36.5 \%$ of the respondents are lying in between 26-35 years of age, $16.8 \%$ of the respondents are between $36-45$ years of age, and lastly $12.6 \%$ of the respondent are above 46 years of age. Majority of the respondents belonged to young age group. The mean score for respondents' age is 2.08 and the standard deviation is 1.006 (Standard Errors of Mean is 0.060). From the above table-II, it is found that out of 285 respondents; $77.2 \%$ of respondents are graduate degree holders, $22.5 \%$ of the respondents are post graduate degree holders, and only $0.4 \%$ of the respondent were having S.S.C degree. The mean score for respondents' educational qualification is 3.22 , and the standard deviation is 0.438 (Standard Errors of Mean is 0.026). The table-II also shows that most of the respondents under study are married, i.e., $51.6 \%$ of the respondents are married, and $48.4 \%$ of them are unmarried. The mean score for respondents' marital status is 1.49, and the standard deviation is 0.508 (Standard Errors of Mean is 0.030). The table-II also demonstrates that out of 285 respondents; $43.5 \%$ have been working for 1 to 5 years, $17.5 \%$ have been working 
for 6 to 10 years, $23.2 \%$, for 11 to 15 years, $12.3 \%$, for 16 to 20 years, and only $3.5 \%$, for 20 and above. The mean score for respondents' job experience is 2.15, and the standard deviation is 1.207 (Standard Errors of Mean is 0.072).
For correlation analysis, the Pearson Product Moment correlation coefficient has been estimated as the sample correlation coefficient in the following table 3:

Table 3: Correlation between job satisfaction; affective commitment; continuance commitment; normative commitment \& work-related factors

\begin{tabular}{|c|c|c|c|c|c|}
\hline \multicolumn{2}{|c|}{$\begin{array}{l}\text { Variables } \\
\text { (i) }\end{array}$} & $\begin{array}{c}\text { Job satisfaction } \\
\text { (ii) }\end{array}$ & $\begin{array}{l}\text { Affective commitment } \\
\text { (iii) }\end{array}$ & $\begin{array}{c}\text { Continuance commitment } \\
\text { (iv) }\end{array}$ & $\begin{array}{c}\text { Normative commitment } \\
(\mathrm{v})\end{array}$ \\
\hline \multirow{2}{*}{$\begin{array}{c}\text { Work and } \\
\text { working } \\
\text { environment }\end{array}$} & Pearson correlation & $.229 * *$ & .016 & $.117^{*}$ & .105 \\
\hline & Sig. (2-tailed) & .000 & .794 & .049 & .076 \\
\hline \multirow{2}{*}{$\begin{array}{c}\text { Supervisor and } \\
\text { supervision }\end{array}$} & Pearson correlation & $.223^{* *}$ & .110 & .023 & $.166^{* *}$ \\
\hline & Sig. (2-tailed) & .000 & .064 & .695 & .005 \\
\hline \multirow{2}{*}{$\begin{array}{c}\text { Work hours and } \\
\text { work group }\end{array}$} & Pearson correlation & $.272^{* *}$ & .049 & .046 & .034 \\
\hline & Sig. (2-tailed) & .000 & .410 & .434 & .567 \\
\hline \multirow{2}{*}{$\begin{array}{l}\text { Reward and } \\
\text { recognition }\end{array}$} & Pearson correlation & $.339^{* *}$ & .024 & .014 & $.157^{* *}$ \\
\hline & \begin{tabular}{|l|} 
Sig. (2-tailed) \\
\end{tabular} & .000 & .684 & .818 & .008 \\
\hline \multirow[t]{2}{*}{ Job security } & Pearson correlation & $.194^{* *}$ & -.078 & .059 & .028 \\
\hline & Sig. (2-tailed) & .001 & .187 & .324 & .636 \\
\hline \multirow{2}{*}{$\begin{array}{l}\text { Training and } \\
\text { development }\end{array}$} & Pearson correlation & .116 & .116 & .104 & .058 \\
\hline & \begin{tabular}{|l|} 
Sig. (2-tailed) \\
\end{tabular} & .051 & .050 & .080 & .328 \\
\hline \multirow{2}{*}{$\begin{array}{l}\text { Authority and } \\
\text { feedback }\end{array}$} & Pearson correlation & $.300^{* *}$ & $.135^{*}$ & .048 & .080 \\
\hline & Sig. (2-tailed) & .000 & .022 & .419 & .176 \\
\hline
\end{tabular}

${ }^{*}$ Correlation is significant at 0.05 level (2-tailed)

** Correlation is significant at 0.01 level (2-tailed).

Source: outcome of the analysis based on field surveyed data, November-2016 to February-2017

The above table 3 (Column 2 ) shows that $\mathrm{r}=0.229, \mathrm{p}<0.000$; $\mathrm{r}=0.223, \mathrm{p}<0.000 ; \mathrm{r}=0.272, \mathrm{p}<0.000 ; \mathrm{r}=0.339, \mathrm{p}<0.000 ; \mathrm{r}=$ $0.194, \mathrm{p}<0.001 ; \mathrm{r}=0.300, \mathrm{p}<0.000$, which imply that there exist strong significant positive associations between work and working environment and job satisfaction; supervisor \& supervision and job satisfaction; work hours \& work group and job satisfaction; reward \& recognition and job satisfaction; job security and job satisfaction; authority \& feedback and job satisfaction respectively in the commercial banks of Bangladesh under study.

The above table 3 (Column 3) shows that $r=0.116$, $\mathrm{p}<0.050 ; \mathrm{r}=0.135, \mathrm{p}<0.022$ which imply that there are significant positive associations between training \& development and affective commitment; authority \& feedback and affective commitment respectively in the commercial banks of Bangladesh under study.
The above table 3 (Column 4 ) shows that $r=0.117, p<0.049$ which implies there is a significant positive correlation between work \& working environment and continuance commitment in the commercial banks of Bangladesh.

The above table 3 (Column 5) shows that $\mathrm{r}=0.166, \mathrm{p}<0.005$; $r=0.157, p<0.008$ which suggest that there exist significant positive correlations between supervisor \& supervision and normative commitment; reward \& recognition and normative commitment respectively in the commercial banks of Bangladesh under study. A regression analysis was also performed; the overall model fit for regression equation was determined by F statistics. The model specifies positive and statistically significant relationship. In order to prove the impact of each of the independent variables on dependent variable and to check the hypothesis developed, a linear regression analysis was applied. Results of the regression analysis are presented in the following table 4 .

Table 4: Model Summary

\begin{tabular}{|c|c|c|c|c|c|c|c|}
\hline Model & $\mathrm{R}$ & R Squared & Adjusted R Squared & Std. Error of the Estimate & R Squared Change & F Change & Sig. F Change \\
\hline 1 (Job Satisfaction) & $.595^{\mathrm{a}}$ & .354 & .335 & 8.320 & .354 & 18.873 & .000 \\
\hline 2 (Affective Commitment) & $.239^{\mathrm{a}}$ & .057 & .030 & 3.040 & .057 & 2.087 & .037 \\
\hline 3 (Continuance Commitment) & $.186^{\mathrm{a}}$ & .035 & .007 & 3.646 & .035 & 1.238 & .277 \\
\hline 4 (Normative Commitment) & $.261^{\mathrm{a}}$ & .068 & .041 & 5.260 & .068 & 2.527 & .011 \\
\hline
\end{tabular}

aPredictors: (Constant), authority \& feedback, supervisor \& supervision, reward \& recognition, job security, training \& development, work hours \& work group and work \& working environment.

From Table 4, the results of the model-1 show that $\mathrm{R}$ is 0.595 ( $\mathrm{p}=0.000$ ), which means authority \& feedback, supervisor \& supervision, reward \& recognition, job security, training \& development, work hours \& work group and work \& working environment are 59.5\% correlated with job satisfaction. The value of $R^{2}, 0.354$ 
means $35.4 \%$ variation in the dependent variable is explained by the present independent variables. The value of Adjusted R Squared is 0.335 which is closed to value of $\mathrm{R}$ Squared Change, 0.354 . The value of $\mathrm{F}$ change is 18.873 and value of Sig. F Change is 0.000 .

In Table 4 , the result of the model-2 presents that $\mathrm{R}^{2}=$ 0.057. The dependent variable is explained by independent variable $5.7 \%$. The value of $\mathrm{R}$ is 0.239 ( $\mathrm{p}=$ 0.037) means that authority \& feedback, supervisor \& supervision, reward \& recognition, job security, training \& development, work hours \& work group and work \& working environment are $23.9 \%$ correlated with Affective Commitment. The value of Adjusted R Squared is 0.030 which is closed to R Squared Change, 0.057 . The value of F change is 2.087and the value Sig. F Change is 0.037.

From Table 4, the result of the model-3 demonstrates that $\mathrm{R}^{2}=0.035$. Hence, $3.50 \%$ variation in the dependent variable is explained by the present inputs. The value of
$\mathrm{R}$ is 0.186 ( $\mathrm{p}=0.277$ ) means that authority \& feedback, supervisor \& supervision, reward \& recognition, job security, training \& development, work hours \& work group and work \& working environment are $18.6 \%$ correlated with continuance commitment. The value of Adjusted R Squared is 0.007 which is closed to the value of $\mathrm{R}$ Squared Change, 0.035 . The value of $\mathrm{F}$ change is 1.238 and the value of Sig. F Change is 0.277 .

From table 4 , the result of model- 4 explains that $R^{2}=0.068$. So, $6.8 \%$ variation in the value of dependent variable is explained by independent variables involved. The value of $\mathrm{R}$ is 0.261 ( $\mathrm{p}=0.011$ ) means that authority \& feedback, supervisor \& supervision, reward \& recognition, job security, training \& development, work hours \& work group and work \& working environment are $26.1 \%$ correlated with normative commitment. The value of Adjusted R Squared is 0.041 which is closed to that of $\mathrm{R}$ Squared Change, 0.068 . The value of $\mathrm{F}$ change is 2.527 and the value Sig. F Change is 0.011 .

Table 5: Coefficients between job satisfaction and work-related factors; affective commitment and work-related factors; continuance commitment and work-related factors, normative commitment and work-related factors

\begin{tabular}{|c|c|c|c|c|c|c|c|c|}
\hline & \multicolumn{4}{|c|}{$\begin{array}{c}\text { Unstandardized } \\
\text { Coefficients (B) }\end{array}$} & \multicolumn{3}{c|}{ Sig. } \\
\hline & $\begin{array}{c}\text { Job } \\
\text { Satisfaction }\end{array}$ & $\begin{array}{c}\text { Affective } \\
\text { Commitment }\end{array}$ & $\begin{array}{c}\text { Continuance } \\
\text { Commitment }\end{array}$ & $\begin{array}{c}\text { Normative } \\
\text { Commitment }\end{array}$ & $\begin{array}{c}\text { Job } \\
\text { Satisfaction }\end{array}$ & $\begin{array}{c}\text { Affective } \\
\text { Commitment }\end{array}$ & $\begin{array}{c}\text { Continuance } \\
\text { Commitment }\end{array}$ & $\begin{array}{c}\text { Normative } \\
\text { Commitment }\end{array}$ \\
\hline (Constant) & 26.589 & 30.308 & 19.412 & 18.411 & .002 & .000 & .000 & .001 \\
\hline Work \& Working Environment & 1.132 & -.009 & .268 & .162 & .000 & .935 & .048 & .406 \\
\hline Supervisor \& Supervision & 1.104 & .156 & -.026 & .483 & .000 & .149 & .841 & .010 \\
\hline Work hours \& work group & .907 & .049 & .097 & -.028 & .001 & .620 & .411 & .868 \\
\hline Reward \& recognition & 1.311 & .026 & -.022 & .381 & .000 & .760 & .828 & .009 \\
\hline Job security & .808 & -.130 & .054 & .080 & .000 & .120 & .589 & .581 \\
\hline Training \& development & .027 & .018 & .019 & .009 & .259 & .038 & .060 & .541 \\
\hline Authority \& Feedback & 1.174 & .170 & .063 & .183 & .000 & .028 & .490 & .168 \\
\hline
\end{tabular}

Coefficient analysis shows the relationship between dependent variable and independent variables. The equation of coefficient analysis is-

$Y=\alpha+\beta_{1} X_{1}+\beta_{2} X_{2}+\beta_{3} X_{3}+\beta_{4} X_{4} \ldots \ldots . \beta_{n} X_{n}$

$Y=\alpha+\beta_{1} X_{1}+\beta_{2} X_{2}+\beta_{3} X_{3}+\beta_{4} X_{4}+\beta_{5} X_{5}+\beta_{6} X_{6}+\beta_{7} X_{7}+€$

The Table 5 shows that Regression function of Job Satisfaction is $\mathrm{Y}=$

$26.589+1.132 \mathrm{X}_{1}+1.104 \mathrm{X}_{2}+0.907 \mathrm{X}_{3}+1.311 \mathrm{X}_{4}+0.808 \mathrm{X}_{5}+0.027 \mathrm{X}$ $6+1.174 X_{7}+€$.

From this equation, it can be found that authority \& feedback $(\beta=\mathbf{1 . 1 7 4}, \mathrm{p}=\mathbf{0 . 0 0 0 )}$; reward \& recognition $(\beta=1.311, p=0.000)$ are highly influential factors among all work-related factors crafting job satisfaction in the commercial banks of Bangladesh under study.

The Table 5 presents that Regression function for Affective Commitment, which is

$\mathrm{Y}=30.308+(-.009) \mathrm{X}_{1}+0.156 \mathrm{X}_{2}+0.049 \mathrm{X}_{3}+0.026 \mathrm{X}_{4}+(-.130)$ $\mathrm{X}_{5}+0.018 \mathrm{X}_{6}+0.170 \mathrm{X}_{7}+€$. From this equation, it is found that authority \& feedback $(\beta=0.170, p=0.028)$ is highly influential factors among all work-related factors making affective commitment in the commercial banks of Bangladesh under study.
The Table 5 demonstrates that Regression function for continuance commitment, which is

$\mathrm{Y}=19.412+0.268 \mathrm{X}_{1}+(-.026)$

$\mathrm{X}_{2}+0.097 \mathrm{X}_{3}+(-.022) \quad \mathrm{X}_{4}+$ $0.054 X_{5}+0.019 X_{6}+0.063 X_{7}+€$.

From this equation, it is found that work \& working environment $(\beta=0.268, p=0.048)$ is highly influential factors among all work-related factors of crafting continuance commitment in the commercial banks of Bangladesh.

Lastly, the Table 5 shows that Regression function for the Normative Commitment is $\mathrm{Y}=18.411+0.162 \mathrm{X}_{1}+0.483 \mathrm{X}_{2}+(-$ .028) $\mathrm{X}_{3}+0.381 \mathrm{X}_{4}+0.080 \mathrm{X}_{5}+0.009 \mathrm{X}_{6}+0.183 \mathrm{X}_{7}+€$. From this equation, it is found that supervisor \& supervision $(\beta=0.483$, $\mathrm{p}=0.010)$; reward \& recognition $(\beta=0.381, \mathrm{p}=0.009)$ are highly influential factors among all work-related factors crafting normative commitment in the commercial banks of Bangladesh. The results of ANOVA have been shown to decide about predetermined hypotheses in the table 6 : 
Table 6: Hypotheses Testing

\begin{tabular}{|c|c|c|c|c|c|c|}
\hline \multicolumn{2}{|c|}{ Variables } & $\begin{array}{c}\text { Sum of } \\
\text { Squares }\end{array}$ & df & $\begin{array}{c}\text { Mean } \\
\text { Square }\end{array}$ & $\mathrm{F}$ & Sig. \\
\hline \multirow{4}{*}{\begin{tabular}{c} 
Job $\begin{array}{c}\text { Jobisfaction } \\
\text { (I) }\end{array}$ \\
\cline { 2 - 8 }
\end{tabular}} & Regression & 10450.970 & 8 & 1306.371 & 18.873 & $.000^{\mathrm{a}}$ \\
\cline { 2 - 8 } & Residual & 19104.679 & 276 & 69.220 & & \\
\hline $\begin{array}{c}\text { Affective } \\
\text { Commitment } \\
\text { (II) }\end{array}$ & Regression & 154.284 & 8 & 19.286 & 2.087 & $.037^{\mathrm{a}}$ \\
\cline { 2 - 8 } & Residual & 2550.979 & 276 & 9.243 & & \\
\cline { 2 - 8 } & Total & 2705.263 & 284 & & & \\
\hline $\begin{array}{c}\text { Continuance } \\
\text { Commitment (III) }\end{array}$ & Regression & 131.645 & 8 & 16.456 & 1.238 & $.277^{\mathrm{a}}$ \\
\cline { 2 - 8 } & Residual & 3668.299 & 276 & 13.291 & & \\
\hline \multirow{2}{*}{$\begin{array}{c}\text { Normative } \\
\text { Commitment } \\
\text { (IV) }\end{array}$} & Regression & 559.324 & 8 & 69.915 & 2.527 & $.011^{\mathrm{a}}$ \\
\cline { 2 - 8 } & Residual & 7636.027 & 276 & 27.667 & & \\
\cline { 2 - 8 } & Total & 8195.351 & 284 & & & \\
\hline
\end{tabular}

apredictors: (Constant), authority \& feedback, supervisor \& supervision, reward \& recognition, job security, training \& development, work hours \& work group and work \& working environment.

aDependent Variable: Job Satisfaction, Affective Commitment, Continuance Commitment, Normative Commitment
Table 6, row 1 demonstrates that, based on hypotheses testing, the $\mathrm{P}$ value of job satisfaction is 0.000 . So, it rejects the null hypothesis at $1 \%$ level of significance which means there is a positive strong significant association between job satisfaction and work-related factors in the commercial bank of Bangladesh. Table 6, row 2 demonstrates that the $\mathrm{P}$ value of affective commitment is 0.037 . So, it rejects the null hypothesis at $5 \%$ level of significance which means there is a positive significant association between affective commitment and workrelated factors in the commercial bank of Bangladesh. Table 6 , row 3 demonstrates that the $P$ value of continuous commitment is 0.277 . So, it rejects the alternative hypothesis at $5 \%$ level of significance which means there is no positive significant association between continuous commitment and work-related factors in the commercial bank of Bangladesh. Table 6, row 2 demonstrates that the $\mathrm{P}$ value of normative commitment is 0.011 . So, it accepts the alternative hypothesis at $5 \%$ level of significance which means there is no positive significant association between normative commitment and work-related factors in the commercial bank of Bangladesh.

Table 7: Results of the Hypotheses Testing

\begin{tabular}{|c|l|c|}
\hline Hypotheses & \multicolumn{1}{|c|}{ Description } & Result \\
\hline $\mathrm{H}_{1}$ & $\begin{array}{l}\text { There exists a positive and significant association between job satisfaction and work-related factors } \\
\text { in the commercial banks of Bangladesh under study. }\end{array}$ & Supported \\
\hline $\mathrm{H}_{2}$ & $\begin{array}{l}\text { There is an association between affective commitment and work-related factors in the commercial } \\
\text { banks of Bangladesh under study. }\end{array}$ & Supported \\
\hline $\mathrm{H}_{3}$ & $\begin{array}{l}\text { There is a positive and significant association between continuance commitment and work-related } \\
\text { factors in the commercial banks of Bangladesh under study. }\end{array}$ & Rejected \\
\hline $\mathrm{H}_{4}$ & $\begin{array}{l}\text { There is a positive and significant association between normative commitment and work-related } \\
\text { factors in the commercial banks of Bangladesh under study. }\end{array}$ & Supported \\
\hline
\end{tabular}

Source: Based on the results from table 6

\section{Conclusion}

In the present study work-related factors, namely authority \& feedback, supervisor \& supervision, reward \& recognition, job security, training \& development, work hours \& work group and work \& working environment have been found to be the influential factors crafting job satisfaction and organizational commitment. The results of this study recognized that there exist positive and significant associations between job satisfaction and work-related factors; affective commitment and work-related factors, and normative commitment and work-related factors in the commercial bank of Bangladesh. But there is no positive association between continuous commitment and workrelated factors in the commercial banks under study. Four hypotheses have been developed and tested for fulfilling the research objectives. In the first hypotheses $\left(\mathrm{H}_{1}\right)$, it is said that there exists a significant positive association of work related factors with job satisfaction in the commercial banks of Bangladesh. The second $\left(\mathrm{H}_{2}\right)$ and fourth $\left(\mathrm{H}_{4}\right)$ hypotheses indicated that affective and normative commitment are positively and significantly associated with work-related factors but third hypothesis $\left(\mathrm{H}_{3}\right)$ gave reverse indication which means that work related factors have no relationship with continuance component of organizational commitment in the commercial banks of Bangladesh.

Based on the correlation analysis it has been found that reward \& recognition and authority \& feedback are two factors which are highly influential in crafting job satisfaction. But training and development is the least influential factor crafting job satisfaction. In case of creating affective commitment, 'authority \& feedback' has been found to more influential factor than the other six work related factors. Job security is negatively associated with affective commitment in the commercial banks under study. Work \& working environment is positively and significantly associated with continuance commitment. On the other hand, reward \& recognition is least influential factor creating continuance commitment in the commercial banks of Bangladesh under study. Lastly, supervisor \& supervision and reward \& recognition are significantly and positively associated with normative commitment. The job security has been found to the least significant factor generating normative commitment in the commercial banks under study. 


\section{REFERENCES}

Awang, Z., Ahmad J. H., and Zin, Z. M., (2010). "Modelling Job Satisfaction and Work Commitment among Lecturers: A Case of UiTM Kelantan, Proceedings of the Regional Conference on Statistical Sciences (RCSS'10)," https://www.researchgate.net/publication/266294260_Model ling_Job_Satisfaction_And_Work_Commitment_Among_Lectu rers_A_Case_Of_UiTM_Kelantan, June 2010, 241-255.

Busch T., Fallan L., and Pettersen A., (1998). “Disciplinary differences in job satisfaction self-efficacy, goal commitment and organizational commitment among faculty employees in Norwegian Colleges: An empirical assessment of indicators of performance", Quality in Higher Education, 4(2), 137- 157.

Çelik C., (2008). "Relationship of Organizational Commitment and Job Satisfaction: A Field Study of Tax Office Employees." International Conference on Management and Economics (ICME2008), 138-155

Chiu-Yueh, T. (2000). "A Study on the Relationship among Organizational Commitment, Job Satisfaction and Organizational Citizenship Behaviour of Nursing Personnel," Unpublished Master's Thesis, Department of Human Resource Management, http:/ /etd.lib.nsusu.

Curry, J. P., Wakefield, D.S., Price, J.L. and Mueller, C. W. (1986). “On the Causal Ordering of Job Satisfaction and Organizational Commitment", The Academy of Management Journal, 29(4). 847858.http://www.jstor.org/stable/255951

Daneshfard C. \& Ekvaniyan K. E., (2012). "Organizational Commitment and Job Satisfaction in Islamic Azad University", Interdisciplinary Journal of Contemporary Research in Business, 3 (9), pp. 168-181.

Eslami J., and Gharakhani D., (2012). “Organizational Commitment and Job Satisfaction." ARPN Journal of Science and Technology, 2 (2), 85-91.

Freund A., (2005). "Commitment and Job Satisfaction as Predictors Turnover Intentions among Welfare Workers", Administration in Social Work, 29(2), 5-21.

Kabir, A. J. (2018). Factors Contributing to the Entrepreneurial Development in Bangladesh: A Study on Rajshahi City. Asian Business Review, 8(2), Art. \#7, pp. 4958. https://doi.org/10.18034/abr.v8i2.149

Khan, A.S. and Jan, F. (2014). "The Job Satisfaction of District Officers in the Developing State Like, Pakistan: A Survey of Local Government of Khyber Pakhtunkhwa," Global Journal of Management and Business Research (A) Volume XIV Issue VIII Version I pp.32-33).

Kreitner R., and Kinicki A., (2006). “Organizational Behavior”, New York: McGraw Hill.

Luthans, F. (2011). “Organizational Behavior- An Evidence Based Approach," $12^{\text {th }}$ edition, Mc-Graw- Hill Irwin), p. 141.

Luthans, F., Baack, D. and Taylor, L. (1987). “Organizational Commitment: Analysis of Antecedents," Human Relations. 40, No. 4, 1987, pp. 219-236; also see Joan E. Finnegan, "The Impact of Person and Organizational Values on Organizational Commitment," Journal of Occupational and Organizational Psychology. 73, 2000, pp. 149-169.

Mannheim B., Baruch Y., and Tal J., (1997). "Alternative models for antecedents and outcomes of work centrality and job satisfaction of high-tech personnel," Human Relations, 50(2), 1537-1562.

Meyer J. P., Stanley D. J., Herscovitch L. and Topolnytsky L., (2002). "Affective, Continuance, And Normative Commitment to the Organization: A Meta-Analysis of Antecedents, Correlates, and Consequences." Journal of Vocational Behavior, 61(1), 20-52.
Meyer, J. P., Allen N. J., and Smith, C. A. (1993). "Commitment to Organizations and Occupations: Extension and Test of a ThreeComponent Conceptualization," Journal of Applied Psychology, 78 (4), 538-551.

Meyer, J. P., and Allen N. J. (1997). "Commitment in the Workplace: Theory, Research, and Application," Sage Publications, Inc.

Morris, J. H., and Steers, R. M. (1980). "Structural influences on organizational commitment" Journal of Vocational Behavior, Volume 17, Issue 1, August 1980, Pages 50-57.

Mowday, R., Porter, L., and Steers, R. (1982). "EmployeeOrganization Linkages: The Psychology of Commitment, Absenteeism, and Turnover," New York: Academic Press.

Mulinge, M.M. (2000). "Toward an Explanation of Cross-Sector Differences in Job Satisfaction and Organizational Attachment among Agricultural Technicians in Kenya," African Sociological Review 4(1), pp.55-73. http://www.codesria.org/Links/Publi cations/asr41full/mulinge.pdf)

Murray L. P., Gregoire M. B., and Downey R. G., (1991). "Organizational Commitment of Management Employees in Restaurant Operations," Hospitality Research Journal, 14, 339-348.

Nawab, S., and Bhatti, K. K., (2011). "Influence of Employee Compensation on Organizational Commitment and Job Satisfaction: A Case Study of Educational Sector of Pakistan," International Journal of Business and Social Science Vol. 2 No. 8, pp. $25-32$

Norizan I., (2012). “Organizational Commitment and Job Satisfaction among Staff of Higher Learning Education Institutions in Kelantan," (Doctoral Dissertation, University Utara Malaysia), 1-73.

Nunn J. (2000). "Career Planning Key to Employee Retention", Journal of Property Management, 65 (5), 20-21.

Nunnally, J.C. (1978). "Psychometric Theory", McGraw-Hill series in psychology, $2^{\text {nd }}$ Edition, McGraw-Hill, 1978.

O'Leary-Kelly, A. M. and Griffin, R.W. (1995). "Job Satisfaction and Organizational Commitment" in "Psychology and Policing," edited by Neil Brewer and Garlene Wilson, Lawrence Erlbaum Associates Inc. p.373).

Okpara J. O., (2004). "Job Satisfaction and Organizational Commitment: Are There Differences Between American And Nigerian Managers Employed in The US MNCs in Nigeria?

Porter L., Steers R., Mowday R., and Boulian P., (1974). “Organizational Commitment, Job Satisfaction, and Turnover among Psychiatric Technicians", Journal of Applied Psychology, 59 (5), 603-609.

Sokoya, SK (2000). "Personal predictors of job satisfaction for the public sector manager: Implications for Management practice and development in a developing economy," The journal of Business in Developing Nation. 4(1). Available online at: (www.ewp.rpi.edu/jbdm) accessed on 4th, March, 2009).

Steers, R. M. (1977). "Antecedents and outcomes of organizational commitment," Administrative Science Quarterly, 22, Sage Publications, Inc. on behalf of the Johnson Graduate School of Management, Cornell University 46-56.

Tella, A., Ayeni C.O., and Popoola, S.O., (2007). “Work Motivation, Job Satisfaction, and Organizational Commitment of Library Personnel in Academic and Research Libraries in Oyo State, Nigeria," Library Philosophy and Practice (e-journal), 1-16.

$--0--$

Online Archive:

https://abc.us.org/ojs/index.php/abr/issue/archive 